\title{
Selection of kale accesses to dehydration post-harvest by model identity test
}

\author{
Luana Cristina R da Silva ${ }^{1} \mathbb{D}$; Alcinei M Azevedo ${ }^{1} \mathbb{D}$; Carlos E Pedrosa ${ }^{2} \mathbb{D}$; Valter C Andrade Júnior ${ }^{2} \mathbb{D}$; \\ Nermy R Valadares ${ }^{1} \mathbb{D}$; Vanessa V de Araújo ${ }^{1} \mathbb{D}$; Evander A Ferreira ${ }^{1 \mathbb{D}}$
}

'Universidade Federal de Minas Gerais (UFMG), Montes Claros-MG, Brasil; alcineimistico@hotmail.com; luana.silva.rodrigues@hotmail. com; nrvaladares@gmail.com; velosovanessa@ymail.com, evanderalves@yahoo.com.br; ${ }^{2}$ Universidade Federal de Lavras (UFLA), LavrasMG, Brasil; carlosenrrik@yahoo.com.br; valter.andrade@dag.ufla.br

\begin{abstract}
The selection of kale genotypes more resistant to dehydration is important, since this product is marketed fresh and characterized as perishable. For the post-harvest study, the adjustment of regression models is useful. However, when there are many treatments, it is difficult to identify the superior one through the graphical representation of the curves. In this sense, the model identity test groups the curves establishing genotypes that have statistically similar behavior. Thus, we aimed to select kale accesses for postharvest dehydration using the model identity test. The accumulated loss of fresh matter of 22 kale genotypes was evaluated, being 19 of the germplasm bank of the UFVJM and three commercial cultivars (COM). The model identity test was used for the statistical grouping of the regression curves. The UFVJM-19 and UFVJM-32 accessions had lower rates of dehydration as a function of time. The test facilitated the interpretation of the results, with a reduction of 22 to six regression curves, helping to select the best genotypes. The UFVJM-19 and UFVJM-32 accessions are the most indicated because they present lower post-harvest dehydration, being the most recommended for commercialization.
\end{abstract}

Keywords: Brassica oleracea var. acephala, loss of fresh matter, curve grouping, shelf life, conservation.

\section{RESUMO}

Seleção de acessos de couve quanto à desidratação póscolheita pelo teste de identidade de modelos

A seleção de genótipos de couve mais resistentes à desidratação é importante, pois além de ser comercializada in natura, é bastante perecível. Para o estudo pós-colheita o ajuste de modelos de regressão é útil. Porém quando se tem muitos tratamentos torna-se difícil a identificação dos superiores por meio da representação gráfica das curvas. Neste sentido, o teste identidade de modelos agrupa as curvas estabelecendo genótipos que possuem comportamento estatisticamente semelhante. Assim, objetivou-se selecionar acessos de couve quanto à desidratação pós-colheita utilizando o teste de identidade de modelos e avaliar sua eficiência. Avaliou-se a perda acumulada de matéria fresca de 22 genótipos de couve, sendo 19 do banco de germoplasma da UFVJM e três cultivares comerciais (COM). Utilizou-se o teste de identidade de modelos para o agrupamento estatístico das curvas de regressão. Os acessos UFVJM-19 e UFVJM-32 obtiveram menores taxas de desidratação em função do tempo. O teste facilitou a interpretação dos resultados, com redução de 22 para seis curvas de regressão, auxiliando a seleção dos melhores genótipos. Os acessos UFVJM-19 e UFVJM-32 são os mais indicados por apresentarem menor desidratação pós-colheita, sendo os mais recomendados para a comercialização in natura.

Palavras-chave: Brassica oleracea var. acephala, perda de matéria fresca, agrupamento de curvas, vida de prateleira, conservação.

Received on July 22, 2019; accepted on June 18, 2020

$\mathrm{K}$ ale (Brassica oleracea var. acephala) is a much-consumed vegetable in the world, however, because it is commercialized in the fresh form, farmers and traders face problems due to its high perishability. One of the factors associated with kale perishability is postharvest dehydration of the leaves, which can decrease consumer acceptance and increase vegetable waste. Therefore, it is important to select genotypes that present less dehydration during storage. However, in the literature, there are few studies evaluating the dehydration of kale due to the accumulated loss of fresh matter (Calbo \& Ferreira, 2011; Azevedo et al., 2016).

For the selection of genotypes by dehydration rate as a function of time, graphical representation of regression curves is a visual resource indicated because it is easy to interpret in the comparison of the treatments. However, when using a large amount of genotypes, the presentation and interpretation can be difficult (Azevedo et al., 2016). In addition, this strategy does not allow the distinction of genotypes to be statistically the same or different considering these regression curves.

In many articles, genotypes are compared in terms of their regression curve using the multivariate cluster (Puiatti et al., 2013). Although this strategy being useful, it does not take into account tests of hypotheses and level of significance. This can lead to major mistakes in the conclusions. To avoid this problem, the model identity test can be used. (Vasconcelos et al., 2010). The model identity test compares a complete model (considering the 
coefficients of all the regression curves of the genotypes) with a reduced model (considering the coefficients of a single curve adjusted for all genotypes) by the $\mathrm{F}$ test. If the complete and reduced model is similar, statistically by the $\mathrm{F}$ test, we assume that the genotypes have similar behavior (Regazzi, 1993, 1996).

Vasconcelos et al. (2010) proposed a methodology for the grouping of linear regression equations in a study of adaptability and phenotypic stability. The authors verified that it is possible to form groups of genotypes with statistically similar behavior by the method of grouping similar models. Therefore, this statistical approach can be very useful in studies of post-harvest conservation of vegetables, because it allows the identification of statistically superior genotypes.

The objective of this work was to select superior accessions of kale considering their post-harvest dehydration curves by the model identity test.

\section{MATERIAL AND METHODS}

The experiment was conducted at the Federal University of the Jequitinhonha and Mucuri Valleys (UFVJM), Diamantina-MG $\left(18^{\circ} 12^{\prime} 01^{\prime} \mathrm{S}\right.$, $43^{\circ} 34^{\prime} 20^{\prime \prime} \mathrm{W}, 1387 \mathrm{~m}$ altitude). During the period of conduction of the experiment, the average temperature was $18.3^{\circ} \mathrm{C}$ with relative humidity of $80.3 \%$, with few oscillations during this period.

Twenty-two genotypes were evaluated. Nineteen kale accessions (obtained from collections in the region of Diamantina-MG) belonging to the germplasm bank of UFVJM (UFVJM-2, UFVJM-3, UFVJM-4, UFVJM-5, UFVJM-7, UFVJM-8, UFVJM-9, UFVJM-10, UFVJM-13, UFVJM-19, UFVJM-21, UFVJM-22, UFVJM-24, UFVJM-26, UFVJM-27, UFVJM- 32, UFVJM-34 and UFVJM-36), and the cultivar "Manteiga 900" from the company Feltrin ${ }^{\circledR}(\mathrm{COM}-1)$, cultivar "Manteiga" from Vidasul baby ${ }^{\circledR}$ (COM-2) and cultivar "Georgia" from Horticeres ${ }^{\circledR}(\mathrm{COM}-3)$.

The shoots were planted in 72-cell styrofoam trays filled with commercial Plantimax ${ }^{\circledR}$ substrate and kept in a greenhouse in the UFVJM Olericulture Sector for 30 days, in order to provide rooting. After the rooting, the seedlings were transplanted to pots with a capacity of $7.5 \mathrm{~kg}$ of soil filled with Red Latosol and bovine manure in the proportion of $3: 1$. The pots were kept in greenhouse for 30 days with the objective of survival of the seedlings. After this time, the pots were taken to the field, where they remained until the collection of the leaves. Soil and cover fertilization were performed according to the recommendations for the crop (Filgueira, 2008). Twice a week, senescent leaves and sprouts were removed to enable better plant development. The experimental design was a randomized block with twentytwo treatments, four replicates and five plants per plot.

After 90 days in the field, two marketable leaves were collected from each plant. The leaves were kept in the shade under a temperature of $18 \pm 1^{\circ} \mathrm{C}$. The accumulated loss of fresh matter (PAMF) was evaluated by weighing the leaves on analytical balance on days 0 (harvesting time), 1, 2, 3, 4, 5, 7, 9 and 10 . The PAMF was obtained by means of the equation: $\operatorname{PAMF}_{\mathrm{i}}(\%)=$ $100 *\left(\mathrm{P}_{0}-\mathrm{P}_{\mathrm{i}}\right) / \mathrm{P} 0$. Where PAMFi is the accumulated loss of fresh matter at time $\mathrm{i}, \mathrm{P} 0$ is the weight of the leaf of kale at the time of harvest and $\mathrm{Pi}$ is the weight of the leaf of kale at time $i$.

As PAMF tends to stabilize after a long period of storage, the second degree polynomial model was adjusted. The identity test of the models is based on the adjustment of the complete model (considering a curve for each of the genotypes) and a reduced model (considering a single curve for all genotypes). The complete model can be represented as $\mathrm{Y}=\mathrm{X} \beta+\mathrm{e}$, where $\mathrm{Y}$ is the vector of mean PAMF values of each genotype at each time, $\mathrm{X}$ is an incidence matrix, $\beta$ is the vector of all regression coefficients and $\mathrm{e}$ is the vector of errors. The reduced model can be represented by $Z=W \phi+\varepsilon$ where $Z$ is the vector of mean PAMF values observed for each time, $\mathrm{W}$ is an incidence matrix, $\phi$ is a vector with regression coefficients and $\varepsilon$ is an error vector. The regression coefficients were selected using the least squares method $\left(\beta=\left(X^{\prime} X\right)^{-1} X^{\prime} Y\right.$ and $\phi$ $\left.=\left(\mathrm{W}^{\prime} \mathrm{W}\right)^{-1} \mathrm{~W}^{\prime} \mathrm{Z}\right)$.

The sum of squares of parameters, relative to the complete model (SQPc) was estimated by: SQPc $=\beta^{\prime} X^{\prime} Y$, with $2 \mathrm{H}$ degrees of freedom. The total uncorrected sum of squares (SQTot) is given by SQTot $=Y^{\prime} Y$, with Hm degrees of freedom. The sum of squares of the residue (SQRes) is obtained by SQRes $=$ SQTot - SQPc $=Y^{\prime} Y \beta^{\prime} X^{\prime} Y$ with Hm $-2 \mathrm{H}$ degrees of freedom. Where $\mathrm{H}$ is the number of genotypes and $m$ is the number of genotypes over time. The sum of squares of parameters related to the reduced model (SQPr) is given by: $\mathrm{SQPr}=\phi^{\prime} \mathrm{W}^{\prime} \mathrm{Z}$, with two degrees of freedom. The difference between SQPc and SQPr generates the sum of squares of the reduction (SQRed) SQRed = SQPc - SQPr, with $2(\mathrm{H}-1)$ degrees of freedom. The null hypothesis tested was $\mathrm{H} 0=\beta_{1}=\beta_{2}=\ldots=\beta_{\mathrm{I}}$ (the I models are identical). The alternative hypothesis tested was $\mathrm{Ha}=\beta_{\mathrm{i}} \neq \beta_{\mathrm{i}}$, for at least one $i \neq i$ ' (at least one model differs from the others). The value of the $\mathrm{F}$ (Fcalc) statistic is obtained by Fcalc $=[(\mathrm{SQPc}-$ $\mathrm{SQPr}) / 2$ (H - 1)] / [SQRes / (Hm - 2H)].

For the grouping of the models, the calculation of the SQRed among all pairs of regression models is done. This procedure will give $(\mathrm{H}(\mathrm{H}-1))$ / 2 results. If the value of any Fcalc is not significant, the pair of genotypes with the lowest Fcalc will form the first group. Based on this first group, the inclusion of a new model (genotype) is tested. This process is repeated until no more genotypes are included. Subsequently, the same procedure is done with the models corresponding to the remaining genotypes, generating other new groups. This methodology is presented in more detail by Vasconcelos et al. (2010).

The analyses were carried out through software R.

\section{RESULTS AND DISCUSSION}

Due to changes in the lifestyle of consumers there is a tendency to buy foods that are concomitantly healthy, 
fresh and present high quality (Dantas et al., 2005). Therefore, the post-harvest conservation study of kale is important, since it is a nutritionally rich food that has been inserted in the market too as minimally processed. In this study, different post-harvest behaviors were found. Because, the model identity test grouped the 22 genotypes into six groups (Table 1).

We verified that the polynomial adjustment of the second degree in this study was satisfactory, with high estimates of the coefficient of determination at average repetition level. This behavior is expected, as PAMF tends to stabilize over time. Optimal adjustments with second degree polynomial regression in post-harvest studies were also obtained by Azevedo et al. (2016). Regression analysis is a potentially useful technique in data analysis, having applications in several areas of knowledge (Regazzi, 1993).

In the regression study of several populations it is in the researcher's interest to know when a set of adjusted equations is identical, that is, if the relation of variables under study can be represented by a single equation (Puiatti et al., 2013). Carneiro et al. (2014) also used the model identity test to compare the growth curves of cattle in five different regions of Northeast Brazil; they observed that the use of a single curve is not adequate. The method of grouping similar models allows to form groups of genotypes with the same statistical behavior (Vasconcelos et al., 2010), therefore, it can be said that the kale accesses that make up each group have the same statistical behavior. This information enables reliable conclusions, since the

Table 1. Mean values of the regression coefficients $(\beta 0, \beta 1$ and $\beta 2)$ and the coefficient of determination $\left(\mathrm{R}^{2}\right)$ obtained from the kale accesses that constituted each cluster, formed by the model identity test, considering an average of repetitions. Diamantina, UFVJM, 2019.

\begin{tabular}{lccccc}
\hline \multirow{2}{*}{ Groups } & \multirow{2}{*}{ Accesses } & \multicolumn{3}{c}{ Coefficients } & \multirow{2}{*}{$\mathbf{R}^{2}$} \\
\cline { 3 - 5 } & & $\beta_{0}$ & $\beta_{1}$ & $\beta_{2}$ & \\
\hline \multirow{2}{*}{1} & UFVJM (8, 13, 7, 10,36, & -0.0236 & 5.0515 & -0.1844 & 0.9988 \\
& 30, 24, 2) & & & & \\
2 & UFVJM (21), COM (1), & 0.1859 & 6.8155 & -0.2862 & 0.9990 \\
3 & UFVJM (3, 26, 22, 27, 5) & & & & \\
4 & UFVJM (19, 32) & -0.1072 & 4.3066 & -0.1547 & 0.9976 \\
4 & UFVJM (4, 34, 9) & 0.8202 & 5.5013 & -0.1869 & 0.9918 \\
5 & COM (2) & -2.3351 & 13.7573 & -0.7040 & 0.9823 \\
6 & COM (3) & -0.9727 & 8.3594 & -0.3930 & 0.9913 \\
\hline
\end{tabular}

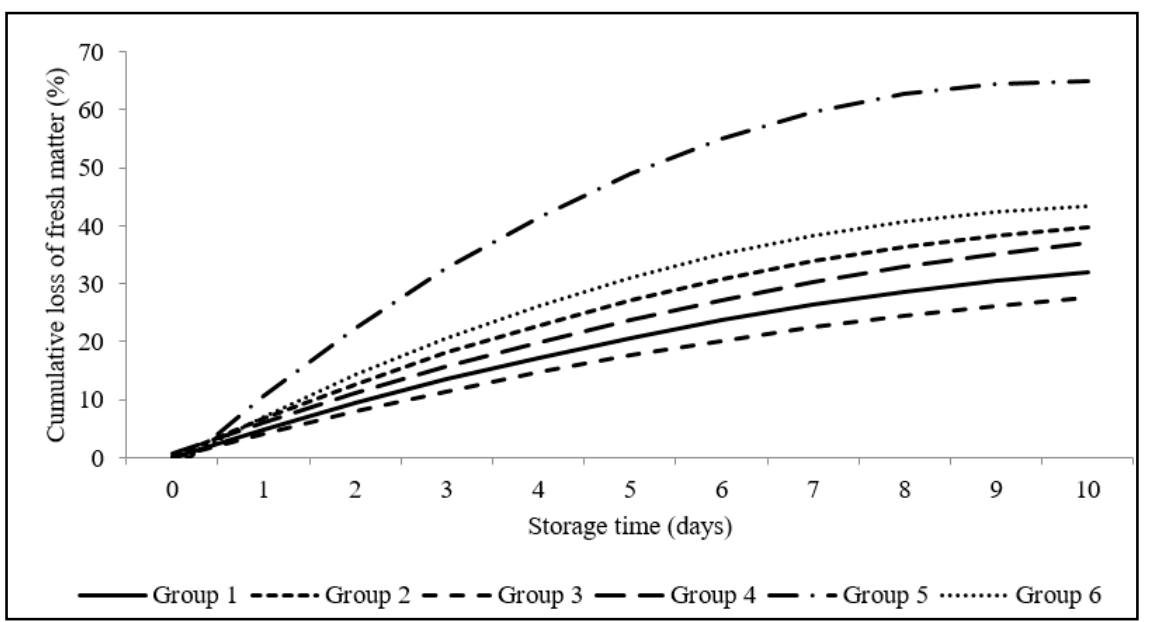

Figure 1. Curves of accumulated loss of fresh matter as a function of storage time in kale leaves for each group formed by the model identity test. Diamantina, UFVJM, 2019.

groupings are based on hypothesis tests, and consequently, considers a level of significance $(\alpha)$. This confidence is not possible in the various works that make the grouping of curves using multivariate techniques. Therefore, although this approach is common, it must be avoided.

The accesses analyzed presented different loss behavior of fresh matter, due to the formation of six different groups. This differential characteristic corroborates with Azevedo et al. (2014) who studied these same accesses and verified high levels of dissimilarity. The different behaviors for PAMF found and the dissimilarity between these genotypes (Azevedo et al., 2014) is something desirable. Because it indicates the possibility of selecting superior genotypes, which can be registered as cultivars or used as parents in breeding programs.

From the data of the regression coefficients the graphic representation of the post-harvest behavior of the kale leaves was made, in which the grouping facilitated the interpretation of the graph and the comparative analysis of the kale treatments (Figure 1). The clustering analysis allows the formation of homogeneous groups according to the evaluation of the characteristic of interest, so it brings together individuals in a number of groups such that there is great homogeneity within each group and heterogeneity among them (Silveira et al., 2011; Puiatti et al., 2013).

Group 3, composed of accesses UFVJM-19 and UFVJM-32, suffered less dehydration due to storage time, which is the best result. After five days of storage, about 15 to $20 \%$ of fresh matter was lost and after 10 days the loss was around 25 and $30 \%$. This information complements product quality studies, which seek the longest shelf life.

In contrast, group 5, composed of the COM-2 cultivar, presented the worst result, about $50 \%$ of the fresh matter was lost after five days and after 10 days of storage the accumulated loss rose to 65\%. The COM-2 cultivar excelled in the dehydration curve, presenting high values from the beginning of storage and was the only one to exceed $50 \%$ of 
fresh matter loss. Souza et al. (2010) also found mass losses in cauliflower cultivars during the storage time and after 12 days, losses exceeded $40 \%$, unlike this work, the curves had a simple linear behavior.

The process of fresh matter loss is related to the energy and mass changes between the plant product and the environment, both of which depend on the transpiratory and respiratory rates exerted by the vegetable that seek to establish the dynamic equilibrium. These rates are influenced by the humidity and temperature of the environment and also with the permeability of the outer films of the vegetable, which act as barriers. According to Matos et al. (1997), relative humidity above $75 \%$ increases the rate of weight loss of onion bulbs stored at temperatures between 20 and $35^{\circ} \mathrm{C}$.

By ordering the groups from best to worst as a function of the dehydration suffered by kale leaves, groups 3, 1, 4, 2, 6 and 5 were highlighted, in which the intermediate groups $(1,4,2$ and 6) showed little variation over time, about $10 \%$ of fresh mass loss between the extremes. The three best groups are composed exclusively of the accessions of the germplasm bank of the UFVJM and the two worst are composed by the commercial cultivars.

The majority of the accesses presented behavior superior to the commercial genotypes 2 and 3, that is, they had less loss of fresh matter. Therefore, these genotypes present the potential to integrate breeding programs, guaranteeing the selection of leaves with better conservation at room temperature.

In the course of the experiment, the process of senescence of the leaves occurred naturally due to both the loss of fresh matter and the catalytic reactions that occur after harvesting, in which they directly influence the qualitative losses of the product. In a study with lettuce, Santos et al. (2001) observed that the loss of fresh matter by plants decreased with increasing doses of organic compost in the soil, although this increase provided higher levels of water in the plants. Therefore, in addition to the cultivar, procedures in planting and crop management influence the selection of superior accesses in post-harvest conservation.

In addition to the UFVJM-19 and UFVJM-32 genotypes suffering less dehydration, they also show high productivity of commercial leaves (Azevedo et al., 2012). This shows the importance of these accesses for cultivation and to integrate breeding programs. These genotypes are also indicated for the minimally processed market. The processing favors the conservation of the kale, since it is an important ally to control the loss of water of the product and the packaging acts to reduce the respiratory rate. The multilayer polyolefin package with high permeability keeps the quality of the minimally processed kale, based on the maintenance of the contents of chlorophyll, carotenoids, soluble solids and vitamin $\mathrm{C}$ during 10 days of storage at $5^{\circ} \mathrm{C}$, also presenting high sensorial acceptability (Dantas et al., 2005). This can also be a good alternative for kale.

The grouping of the curves by the model identity test facilitated the presentation and graphic interpretation for the selection of superior kale genotypes for dehydration. The accessions UFVJM-19 and UFVJM-32 obtained lower rates of dehydration as a function of time, being indicated for cultivation and to integrate breeding programs.

\section{REFERENCES}

AZEVEDO, AM; ANDRADE JUNIOR, VC; FERNANDES, JSC; PEDROSA, CE; VALADARES, NR; FERREIRA, MAM; MARTINS, RAV. 2014. Divergência genética e importância de caracteres morfológicos em genótipos de couve. Horticultura Brasileira 32: $48-54$

AZEVEDO, AM; ANDRADE JUNIOR, VC; PEDROSA, CE; FERNANDES, JSC; VALADARES, NR; FERREIRA, MRA; MARTINS, RAV. 2012. Desempenho agronômico e variabilidade genética em genótipos de couve. Pesquisa Agropecuária Brasileira 47: 1751-1758.

AZEVEDO, AM; ANDRADE JUNIOR, VC; PEDROSA, CE; VALADARES, NR; FERREIRA, MAM; CECON, PR. 2016. Longitudinal data assessment of global stability index in kale leaves. Scientia Agricola 73: 79-84.

CALBO, AG; FERREIRA, MD. 2011. Evaluation of hydration indexes in kale leaves. Brazilian Society of Plant Physiology 23: 141-149.

CARNEIRO, APS; MUNIZ, JA; CARNEIRO, PLS; MALHADO, CHM; MARTINS FILHO, R; SILVA, FF. 2014. Identidade de modelos não lineares para comparar curvas de crescimento de bovinos da raça Tabapuã. Pesquisa Agropecuária Brasileira 49: 57-62.

DANTAS, MIS; DELIZA, R; MINIM, VPR; HEDDERLEY, D. 2005. Avaliação da intenção de compra de couve minimamente processada. Ciência e Tecnologia de Alimentos 25: 762767.

FILGUEIRA, FAR. 2008. Novo manual de olericultura. Viçosa: UFV. 412p.

MATOS, AT; FINGER, FL; DALPASQUALE, VA. 1997. Perda de matéria fresca e isotermas de sorção em bulbos de cebola. Pesquisa Agropecuária Brasileira 32: 235-238.

PUIATTI, GA; CECON, PR; NASCIMENTO, M; PUIATTI, M; FINGER, FL; SILVA, AR; NASCIMENTO, ACC. 2013. Análise de agrupamento em seleção de modelos de regressão não lineares para descrever o acúmulo de matéria seca em plantas de alho. Revista Brasileira de Biometria 31: 337-351.

REGAZZI, AJ. 1993. Teste para verificar a identidade de modelos de regressão e a igualdade de alguns parâmetros num modelo polinomial ortogonal. Revista Ceres 40: 176-195.

REGAZZI, AJ. 1996. Teste para verificar a identidade de modelos de regressão. Pesquisa Agropecuária Brasileira 31: 1-17.

SANTOS, RHS; SILVA, F; CASALI, VWD; CONDÉ, AR. 2001. Conservação pós-colheita de alface cultivada com composto orgânico. Revista Pesquisa Agropecuária Brasileira 36: 521-525.

SILVEIRA, FG; SILVA, FF; CARNEIRO, PLS; MALHADO, CHM; MUNIZ, JA. 2011. Análise de agrupamento na seleção de modelos de regressão não-lineares para curvas de crescimento de ovinos cruzados. Ciência Rural 41: 692-698.

SOUZA, AM; GIOPPO, M; GONÇALVES, J; AYUB, RA; REZENDE, BLA; OTTO, RF. 2010. Caracterização pós-colheita de dois híbridos de couve-flor. Biotemas 23: 45-49.

VASCONCELOS, ES; CRUZ, CD; REGAZZI, AD; BHERING, LL; ROSADO, TB; VASCONCELOS, FS. 2010. Agrupamentos de modelos de regressão da análise de adaptabilidade e estabilidade de genótipos. Pesquisa Agropecuária Brasileira 45: 13571362. 